BENTHAM OPEN
CrossMark
Content list available at: www.benthamopen.com/TOBIOTJ/
DOI: $10.2174 / 1874070701610010363$

REVIEW ARTICLE

\title{
Bioremediation of Polycyclic Aromatic Hydrocarbon (PAHs): A Perspective
}

\author{
Akshaya Gupte ${ }^{*}, 1$, Archana Tripathi ${ }^{1}$, Helina Patel $^{1}$, Darshan Rudakiya $^{1}$ and Shilpa Gupte ${ }^{2}$

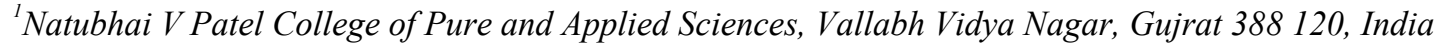 \\ ${ }^{2}$ Ashok and Rita Patel Institute of Integrated Study and Research in Biotechnology and Allied Sciences, New Vallabh \\ Vidya Nagar, Gujrat 388121, India
}

\begin{abstract}
Hydrocarbon pollution is a perennial problem not only in India but throughout the globe. A plethora of microorganisms have been reported to be efficient degraders of these recalcitrant pollutants. One of the major concerns of environmental problem is the presence of hydrocarbons due to the various anthropogenic activities. PAHs are ubiquitous in nature i.e. present in soil, water and air. Presence of PAHs in environment creates problem as their presence have deleterious effect on human and animals. They also have the ability to cause the tumors in human and animals. Some of the microorganisms are capable of transforming and degrading these PAHs and remove them from the environment. The present review describes about the sources, structure, fate and toxicity of PAHs as well as different bioremediation techniques involved in the removing of contaminants from the environment which are efficient and cost-effective. The conventional approaches used for removal of PAH are not only environment friendly but also are able to reduce the risk to human and ecosystem.
\end{abstract}

Keywords: Bioremediation, Contaminants, Hydrocarbon, Polycyclic aromatic hydrocarbon.

\section{INTRODUCTION}

Polycyclic Aromatic Hydrocarbons (PAHs) are potent environment pollutants which are ubiquitously distributed, having fused aromatic rings [1,2]. PAHs are formed due to incomplete combustion of wood, coal, oil and gasoline. Presence of PAHs has been reported in crude oil, coal tar and asphalt [3]. Main cause of soil and water pollution is the release of hydrocarbons accidentally or through human activities [4, 5]. PAHs are toxic, carcinogenic and mutagenic so their presence in environment is of great concern and has deleterious effect on human health. 16 PAHs have been listed as priority pollutants by US EPA and are monitored continuously in industrial effluents [6]. Environmental concern has increased and potential techniques have been developed and adopted for overcoming this problem. Bioremediation is a technique which uses microbes (bacteria, fungi and alage) to degrade or transform and mineralize various contaminants to carbon dioxide, water, inorganic salts and other by products. Biodegradation of polycyclic aromatic hydrocarbon (PAHs) has been achieved by bacteria $[7,8]$ fungi $[9,10]$ or algae $[11,12]$.

\section{SOURCES OF PAHS}

Large quantities of hazardous chemicals have been generated over the last century due to the development in industrial, agricultural and medical activities leading to the increase in environmental pollution (Fig. 1). Ubiquitous distribution of PAH and their detrimental effect on human health has prompted the interest of various resources in the mechanism of degradation and their possible fate in nature $[13,14]$. PAHs (also, known as Polyarenes, Polynuclear aromatic Hydrocarbons) are product of incomplete combustion of organic compounds. PAHs are organic pollutants that

\footnotetext{
* Address correspondence to this author at the Natubhai V Patel College of Pure and Applied Sciences, Vallabh Vidya Nagar, Gujrat 388 120, India; Tel: +91 2692 235500; Fax: +91 02692 234111; E-mails: akshaya_gupte@hotmail.com, gupteap@gmail.com
} 
are widely distributed in the environment which are toxic and persistent $[15,16]$. The major source of energy for industry and daily life in the era of industrialization is obtained from petroleum based products. Hence the chances of spillage and leakage occur regularly during the exploration, production, refining, transport and storage of petroleum products. Generally, PAHs are non-polar, neutral, organic molecules which are ubiquitous environmental pollutants which can be found naturally or anthropogenically [17, 18]. Natural sources include volcanoes and forest fires. Anthropogenic sources include [19].

- Combustion of fossil fuel- including motor vehicle emission and power generation.

- Wood burning.

- Municipal and industrial waste inceration.

- Coal tar, coke, asphalt, crude oil, creosote, asphalt roads, roofing tar.

- Discharges from industrial plants and waste water treatment plants.

- Hazardous wastes sites, coal gasification sites, smoke houses, aluminium production plants.

- Atmospheric contamination of leafy plants.

- Cigarette smoke.

- Charbroiled meat

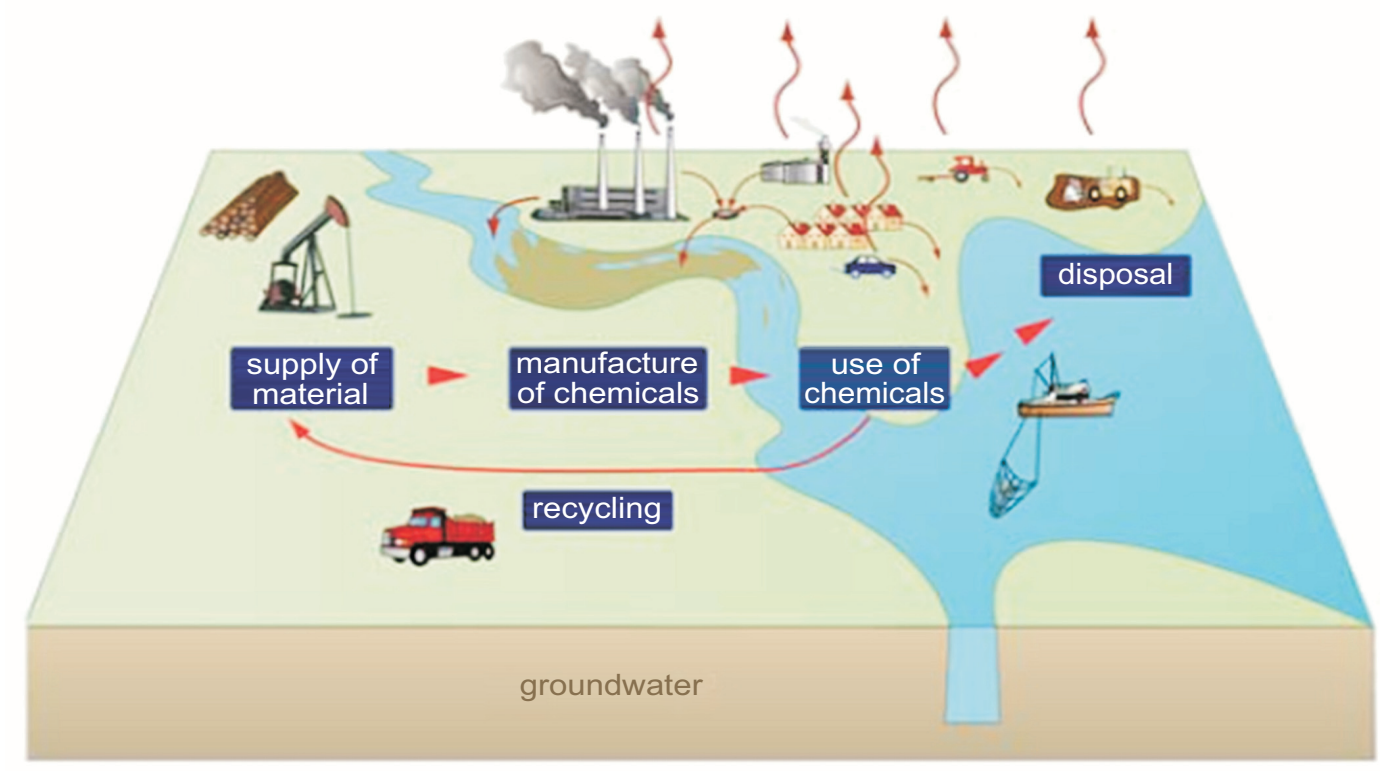

Fig. (1). Transfer of PAHs in the environment. (Source: www.sepa.org.uk).

\section{STRUCTURE OF PAHS}

PAHs, structure consist of carbon \& hydrogen atoms having two or more fused benzene rings in linear, angular or cluster arrangements [20]. The molecular arrangements of PAHs are shown in Fig. (2) [21 - 23]. PAHs with an angular arrangement are more stable than with linear arrangement [24]. PAHs not only contain carbon \& hydrogen but in broader way heterocyclic (heteroatom) i.e. PAH containing N, S and O atoms are also considered to be known as PAH. Generally, molecular weight ranges from 166 to 328. Molecular weight of the compound generally depends on its number as well as position of fused rings and other compounds. PAHs are formed due to thermolysis of various organic molecules in the environment. PAHs are produced as a result of incomplete combustion of organic compound at high temperature $\left(500-800^{\circ} \mathrm{C}\right)$ to low temperature $\left(100-300^{\circ} \mathrm{C}\right)$ for long duration [25]. The PAH molecule exhibits biochemical persistence because of the presence of dense $\pi$ electrons on both sides of ring structure. Hence, PAHs compounds are more resistant to nucleophilic attack [26].

PAHs are flat, crystalline solid with high melting and boiling point but with low vapour pressure and water solubility. PAHs range in appearance from colorless to white or pale yellow-green. On the basis of molecular weight the PAHs are classified as Low Molecular Weight (LMW) having two or three fused benzene rings like Naphthalene, Fluroene, and Phenanthrene and High Molecular Weight (HMW) PAHs are those having four or more fused benzene 
rings like Pyrene [19]. Increase in molecular mass, increases the hydrophobicity/ lipophilicity and decreases water solubility and vapour pressure making the compound become more recalcitrant [27]. So as compared to LMW, HMW are not only poorly bioavailable and recalcitrant to microbial degradation, but are also more carcinogenic, mutagenic and teratogenic [28 - 30]. On the basis of the genotoxicity and abundance US Environmental Protection Agency (USEPA) have listed 16 PAH compounds as priority pollutants as shown in Table 1.

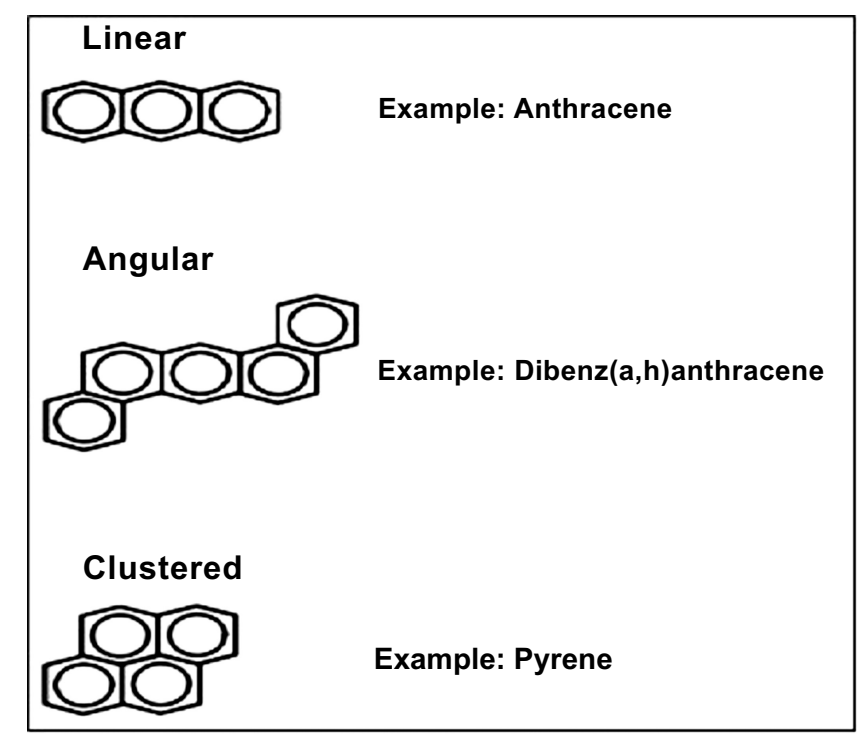

Fig. (2). Molecular arrangement of PAHs.

Table 1. US EPA's 16 Priority pollutant PAHs and selected properties (Lundstedt et al., 2003[31]; Bojes and Pope, 2007[32]).

\begin{tabular}{|c|c|c|c|c|c|}
\hline PAH names & Number of rings & $\begin{array}{l}\text { Molecular weight } \\
\quad\left(\text { g mole }^{-1}\right)\end{array}$ & Solubility in water $\left(\mathrm{mg} \mathrm{L}^{-1}\right)$ & Vapor pressure $(\mathbf{P a})$ & $\log K_{o v}$ \\
\hline Naphthalene & 2 & 128.17 & 31 & 11.866 & 3.37 \\
\hline Acenaphthene & 3 & 154.21 & 3.8 & 0.500 & 3.92 \\
\hline Acenaphthylene & 3 & 152.2 & 16.1 & 3.866 & 4.00 \\
\hline Anthracene & 3 & 178.23 & 0.045 & $3.40 \times 10-3$ & 4.54 \\
\hline Phenanthrene & 3 & 178.23 & 1.1 & $9.07 \times 10-2$ & 4.57 \\
\hline Fluorene & 3 & 166.22 & 1.9 & 0.432 & 4.18 \\
\hline Fluoranthene & 4 & 202.26 & 0.26 & $1.08 \times 10-3$ & 5.22 \\
\hline Benz[a]anthracene* & 4 & 228.29 & 0.011 & $2.05 \times 10-5$ & 5.91 \\
\hline Chrysene* & 4 & 228.29 & 0.0015 & $1.04 \times 10-6$ & 5.91 \\
\hline Pyrene & 4 & 202.26 & 0.132 & $5.67 \times 10-4$ & 5.18 \\
\hline Benzo[a/pyrene* & 5 & 252.32 & 0.0038 & $6.52 \times 10-7$ & 5.91 \\
\hline Benzo/b/fluoranthene* & 5 & 252.32 & 0.0015 & $1.07 \times 10-5$ & 5.80 \\
\hline Benzo/k/fluoranthene* & 5 & 252.32 & 0.0008 & $1.28 \times 10-8$ & 6.00 \\
\hline Dibenz/a,h/anthracene* & 6 & 278.35 & 0.0005 & $2.80 \times 10-9$ & 6.75 \\
\hline Benzo/g,h,ilperylene * & 6 & 276.34 & 0.00026 & $1.33 \times 10-8$ & 6.50 \\
\hline Indeno[1,2,3-cd]pyrene & 6 & 276.34 & 0.062 & $1.87 \times 10-8$ & 6.50 \\
\hline
\end{tabular}

* The US EPS has classified PAH in italics as possible human carcinogens

PAHs are also classified on the basis of their ring structure (a) Alternant (b) Non-Alternant. Alternant PAHs include Anthracene, Phenanthrene and Chrysene which are derived from benzene by fusion of additional 6- membered benzoid ring and contain fewer ring than benzoid ring [33]. Non-Alternant PAH includes Fluoranthene which contain rings with fewer than 6 carbon atoms in addition to 6- membered ring. As shown below in Fig. (3) there is difference in two structures. Chrysene consists of four fused, six carbon benzene rings. Fluoranthene, on the other hand, contains naphthalene and a benzene unit connected by a five-membered ring (in the centre of the structure) and is indicative of lower temperature and less efficient combustion.

Most PAHs consist of a "bay-region", a "K-region" and "L -region". For example an open inner corner of Phenanthrene structure is Bay-region i.e. internal open inner corner. The $\mathrm{K}$ - region is an external closed corner and Lregion represents the pair of opposed anthracenic point atoms [34]. These bay- and K-region epoxides are chemically reactive. Thus, they are developed metabolically and biologically. The bay region between carbon atom 4 and 5 is sterically hindered in Phenanthrene. The most oleinic aromatic double bond with high electron density is the $\mathrm{K}$ region where there is a presence of double bond between carbon 9 and 10 (Fig. 4)[35]. 
Alternant (Chrysene)

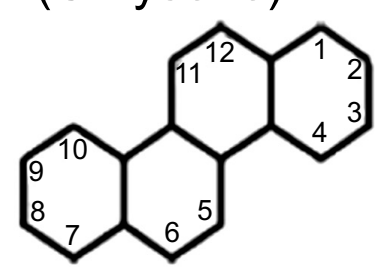

NON-ALTERNANT (Fluoranthene)

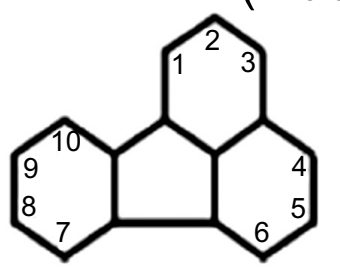

Fig. (3). Structure of alternant and non-alternant PAHs.

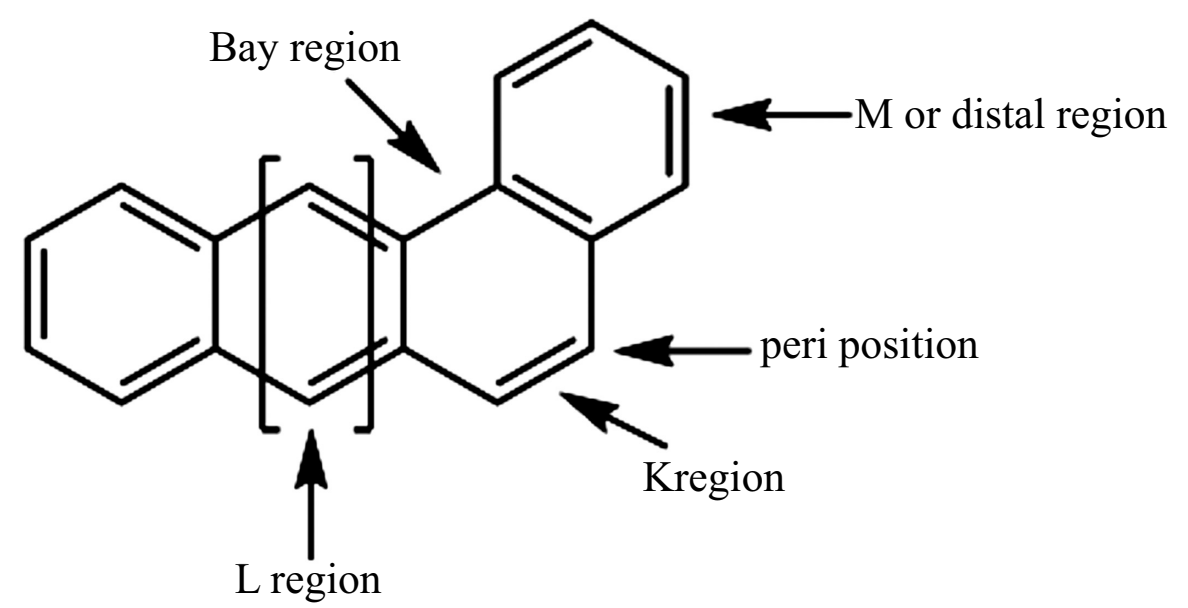

Fig. (4). Structure of phenanthrene.

\section{SOLUBILITY OF PAHS}

As discussed earlier solubility of any compound in water is dependent on temperature, $\mathrm{pH}$, ionic strength (concentration of soluble salts) other organic chemicals (i.e. dissolved organic carbon) [36]. Solubility can be estimated by 2 ways (a) Chemical Structure (b) Octanol-Water Partition Coefficients.

Chemical Structure: Wilson and Jones [17] reported that (a) with increase in benzene rings in PAH there is a decrease in solubility. Planar PAHs are less toxic and less reactive [37].

(b) Octanol-Water Partition Coefficients (Kow): Octanol-Water Partition Coefficients is expressed as an inverse relationship between Kow and solubility which is determined with the following equation

Kow $=\underline{\text { Amount of organic chemical in octanol }(\mathrm{mg} / \mathrm{L})}$

Amount of organic chemical in water $(\mathrm{mg} / \mathrm{L})$.

It is expressed in terms of log Kow. For example: $\log$ Kow of a naphthalene is 3.37 where as that of Indeno [1, 2, 3Cd] Pyrene is 6.50 with lower Kow naphthalene is said to be more soluble. Removal of PAHs from the environment takes place by the process of volatilization, photo-oxidation, chemical oxidation, bioaccumulation, adsorption, microbial degradation and their adhesion to the soil matrix [29, 38 - 40]. PAHs found in soil can under go number of processes it may get bio accumulated by some organisms, low molecular weight PAHs have a tendency to evaporate and can also get adsorbed onto soil particles and organic matter fraction, which may be lost either by leaching/ degradation [41]. Reid et al. [42], and Semple et al. [41], reported that fate of PAHs in soil is affected by various factors like weather and climate, biological diversity and abundance, amount and nature of the soil/minerals which include properties like molecular structure, polarity, solubility, hydrophobicity, lipophilicity, temperature, $\mathrm{pH}$ and moisture content. The persistence of PAHs is also influenced with the 'age' of the co-existing contaminants in the soil matrix. If the age of coexisting contaminants is higher the persistence of PAHs is longer. However, PAHs in the environment can be removed through a natural techniques using microbial degradation or using physical or chemical processes as shown in Fig. (5)[43]. Phenanthrene has shown reduced biodegradability due to depletion of oxygen and increase of anaerobicity in the environment. However, it has been reported that efficiency of PAH degradation under anaerobic 
condition is limited [44, 45]. BTEX (Benzene, Toluene, Ethyl benzene and Xylene) are the compounds which are degraded in-situ by microbes, thereby leading to the depletion of oxygen in the surrounding environment and creating an anaerobic condition [44]. The microbial growth is also inhibited in the presence of heavy metals thus limiting the metabolism of the pollutants under anaerobic condition [46].

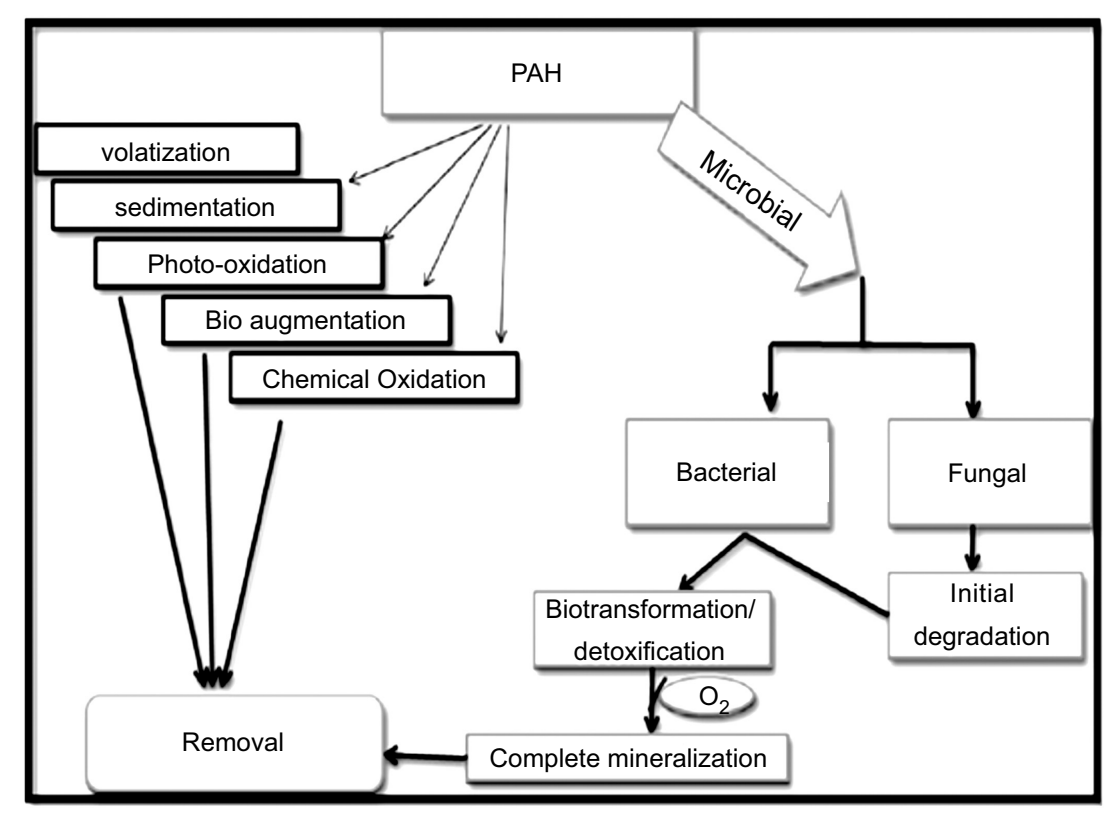

Fig. (5). Fate of PAHs in the environment.

PAH bioavailability for a bioremediation process to be successful the microorganisms, or their enzymes, need to be in physical contact with the organic contaminant. As both the properties of the soil and the type of the contaminant determine bioavailability and bio accessibility [47]. Bioavailability represents the fraction that is taken up by the cell, and causes their toxic effects. Whereas the term bio accessibility means the fraction that is potentially available for biota in soils also known as environmental availability [48]. Two steps are involved in the biodegradation of PAHs in soil. They are (a) uptake of the PAH by microbes (b) break down (metabolism) of the PAH [49]. PAHs degradation, its transport and sequestration is dependent on their bioavailability in environment [50]. The factors responsible for lower degradation of the PAHs are the poor bioavailability which is caused by their lower water solubility, low dissolution rate and strong adsorption to the soil matrix [51]. PAH bioavailability in the environment is affected by various parameters like physical properties, soil characteristics and receptor organisms [12, 52]. Alexander [53] reported that LMW PAHs have the property of volatility, higher solubility and can also be used as a sole source of carbon by micro organisms which could be removed at a faster rate by biological as well as physic-chemical process. Bioavailability of PAHs in the environment changes with time and weathering stage [54]. PAHs bioavailability is influenced by various soil parameters like organic matter content, texture, aggregation and ageing.

\section{TOXICITY OF PAHs}

According to US-EPA among all PAHs known Benzo (a) Pyrene is recognized as the most dangerous pollutant as it is extremely carcinogenic and the major component of smoke released from cigarettes [55]. PAHs are quickly absorbed into the gastro-intestinal tracts of humans as they are highly lipid soluble $[15,56,57]$. The toxicity of any PAHs can be measured using LD50 values. It is expressed as milligrams of toxic material per kilograms of the subject's body weight that will cause death in 50\% of cases. Many PAHs lead to toxic effect in living organisms. Due to their carcinogenic and mutagenic nature PAHs are of significant concern as environmental contaminant [58]. It has been reported by Sims and Overcash [58] that LMW i.e. one, two or three-ring compounds are acutely toxic while HMW PAHs are considered as genotoxic $[59,60]$. The toxicity of PAHs is induced when there is a transformation to reactive products by chemical or biochemical processes, particularly there is incorporation of oxygen into the PAH ring structure. Photoxidation of PAHs increases the toxicity of the compounds. 16 PAHs have been identified as major pollutants regarding to its potential exposure and adverse health effects on humans and animals [21]. Kannaly and Haryama [61] and Cerniglia [29] reported that the genotoxicity of PAHs increases with increase in number of fused benzene rings. PAHs also have 
toxic effect on humans which can lead to nephrotoxicity and haemolytic anemia. About 75\% of PAHs are absorbed through skin. PAHs has fast absorption rate due to its high potential for biomagnifications in the food chain. The effect of PAHs has also been studied on mammalian health. PAHs are known to have acute carcinogenic, mutagenic and teratogenic properties. Among all PAHs, Phenanthrene is a photo-sensitizer of human skin a mild allergen, and mutagenic to bacterial system. Samanta et al. [14], reported that Phenanthrene is smallest PAH which has Bay and Kregion in its structure and hence it is considered as model substrate for studying the metabolism of carcinogenic PAHs. Food may also contain PAHs in varying quantities when exposed to high temperature. It has been suggested in studies that PAHs are also found in oil, fats and cereals. PAHs are also even obtained from cooked meat and vegetables [62]. PAH- contaminated soil is of great concern to human health as it passes into the food chain [63]. The effect on human health will mainly depend on the time and route of exposure as well as on the concentration of the PAHs. Various factor affects human health which include symptoms of eye irritation, nausea, vomiting and diarrhea. PAHs such as Anthracene, Benzo(a) Pyrene and Naphthalene have the ability to cause skin irritation while Anthracene and Benzo(a) Pyrene cause allergic response in animals and humans [29].

PAHs are suspected carcinogens. They become genotoxic when activated by mammalian enzymes to reactive epoxides and quinones by enzymes such as cyctochrome P450 monoxygenase [64]. Harvey [65] reported that the formed intermediates may undergo oxidation and/or hydrolysis before combining DNA for the formation of covalent adducts. The formation of adducts thus leads to mutation resulting in tumors. Movement and fate of PAHs, in the environment is as shown in Table 2.

\section{PAHs DEGRADATION TECHNIQUES}

\section{Chemical Degradation}

Detecting the persistence of PAH after its degradation in environment is quite difficult. The existence of PAH in anaerobic condition depends on substrate interaction, $\mathrm{pH}$ and redox condition [66]. Degradation of PAH in soil occurs through biotic process. Upon undergoing chemical reactions, PAHs are transformed into other derivatives of PAHs. As considerable amount of energy is required to change an aromatic compound into a non- aromatic compound, PAHs do not lose their aromaticity character. The efficiency of PAHs chemical degradation is limited because of their low aqueous solubility and vapour pressure [67]. It has been reported that surfactants have the property to overcome the problems related to PAHs low aqueous solubility [68]. Solubility of PAHs is enhanced in the presence of surfactants by decreasing the interfacial surface tension [69].

Table 2. Movement and fate of organic chemicals, such as PAHs, in the environment (adapted from Pierzynski et al., 2000) $[36]$.

\begin{tabular}{|c|c|c|}
\hline Process & \begin{tabular}{|c|} 
Consequence \\
\end{tabular} & Factors \\
\hline \multicolumn{3}{|c|}{ Transfer (processes that relocate PAHs without altering their structure) } \\
\hline Volatilization & $\begin{array}{l}\text { Loss of PAHs due to evaporation from soil, plant, or aquatic } \\
\text { ecosystems }\end{array}$ & Vapor pressure, wind speed, temperature \\
\hline Absorption & $\begin{array}{l}\text { Uptake of PAHs by plant roots or animal ingestion. Polycyclic } \\
\text { aromatic hydrocarbons usually do no transfer into aboveground } \\
\text { biomass from soil. }\end{array}$ & $\begin{array}{l}\text { Cell membrane transport, contact time, susceptibility, plant } \\
\text { species }\end{array}$ \\
\hline Leaching & Translocation of PAH either laterally or downward through soils & $\begin{array}{l}\text { Water content, macropores, soil texture, clay and organic matter } \\
\text { content, rainfall intensity, irrigation }\end{array}$ \\
\hline Erosion & Movement of PAH by water or wind action & $\begin{array}{l}\text { Rainfall, wind speed, size of clay and organic matter particles } \\
\text { with adsorbed PAH on them }\end{array}$ \\
\hline \multicolumn{3}{|c|}{ Degradation (processes that alter the PAH structure) } \\
\hline Biological & $\begin{array}{l}\text { Degradation of PAHs by microorganisms, biodegradation and } \\
\text { cometabolism }\end{array}$ & $\begin{array}{l}\text { Enviromental factors ( } \mathrm{pH} \text {, moisture, temperature, oxygen), } \\
\text { nutrient status organic matter content, PAH bioavailabilty, } \\
\text { microbial community present, molecular weight of PAH (LMW } \\
\text { or HMW) }\end{array}$ \\
\hline Chemical & $\begin{array}{l}\text { Alteration of PAHs by chemical processes such as photochemical } \\
\text { (i.e. UV light) and oxidation-reduction reactions }\end{array}$ & $\begin{array}{l}\text { High and low } \mathrm{pH} \text {, structure of } \mathrm{PAH} \text {, intensity and duration of } \\
\text { sunlight, exposure to sunlight, and same factors as for microbial } \\
\text { degradation }\end{array}$ \\
\hline \multicolumn{3}{|c|}{ Sequestration (processes that relocate PAHs into long-term storage without altering structure) } \\
\hline Adsorption & $\begin{array}{l}\text { Removal of PAHs from bioavailable pools through intraction with } \\
\text { soils and sediments }\end{array}$ & Clay and organic matter content, clay type, moisture \\
\hline Diffusion & $\begin{array}{l}\text { Diffusion of PAH into soil micropores where it is unavailable for } \\
\text { microbial degradation }\end{array}$ & Hydrophobic nature of micropores and $\mathrm{PAH}$ \\
\hline
\end{tabular}




\section{BIOREMEDIATION}

Bioremediation involves the process of biodegradation and biotransformation where by organic contaminants are transformed or degraded to an environmentally safe levels in ground water and soil [70].The micro-organisms used for the biodegradation may be indigenous to a contaminated area or may be extraneous and brought to the contaminated site. The complete mineralization of the pollutants leads to the generation of $\mathrm{CO}_{2}, \mathrm{H}_{2} \mathrm{O}$ and biomass [71 - 73].

\section{Phytodegradation}

Phytoremediation is an emerging technology that uses various plants to degrade, extract, contain or immobilize contaminants. There are various mechanism like volatilization, rhizoremediation, phytotransformation, phytostabilization, hydraulic control that are used for contaminant of pollutants from air, soil and water. Phytodegradation is also called as Phyto transformation which involves degradation of organic contaminants to simple molecules or the incorporation of these molecules into plant tissues [74, 75]. Adam \& Duncan [76] reported the use of various grasses and leguminous plants having ability to phytodegrade the organic compounds. It has been reported that the tall fescue grass (Festuca arundinacea) and switch grass (Panicum virgatum) have the ability to degrade $38 \%$ of Pyrene in 190 days [77].

\section{Combined Degradation}

The usage of two or more degradation approaches is referred as combined degradation and at present is considered as an approach for the removal of PAHs from contaminated sites. It has advantage over other degradation methods since it is regarded as efficient and cost-effective. Success in combined degradation of PAHs have been documented using pressurize assisted ozonation and integrated treatment using soil washing, ozonation and biological treatment of substrate [78, 79]. Combined degradation and phyto-degradation using inorganic nutrients with E. crassipes is an innovative approach which is gaining a wide acceptability [80].

\section{FACTORS INFLUENCING PAHS DEGRADATION}

The biodegradation of hydrocarbons depends on the amount and nature of the hydrocarbon present as well as on the diversity of microbes present. Degradation of PAH depends upon various physical and chemical factors such as soil, pressure, temperature, humidity, nutrient availability, bioavailability and $\mathrm{pH}$. Degradation of PAH insitu by the microorganisms is highly influenced by temperature. Biodegradation of PAH occurs over a wide range of temperature. At higher temperature bioavailability, solubility and diffusion rate increases which there by enhance the process of biodegradation. However, decrease in oxygen solubility is observed with increase in temperature, thereby reducing metabolic activity of aerobic organisms. Bartha and Bossert [81] and Cooney [82] reported that the maximum degradation occurs at $30-40^{\circ} \mathrm{C}$ in soil environments, $20-30^{\circ} \mathrm{C}$ in freshwater and $15-20^{\circ} \mathrm{C}$ in marine environments. Siron et al. [83], reported the degradation of Naphthalene and Phenanthrene from crude oil in sea water at temperature as low as $0^{\circ} \mathrm{C}$. The enzymatic machinery of ligninolytic fungi (Laccase, MnP) having an optimum temperature of $50^{\circ} \mathrm{C}$ and above $70^{\circ} \mathrm{C}$ reported over $90 \%$ degradation of contaminating PAH in spent-mushroom compost [84]. Degradation of PAH has been recorded in $\mathrm{pH}$ range of 2-9. Wong et al. [85], reported degradation of phenanthrene in liquid culture in the range of $\mathrm{pH}$ 5.5-7.5 with Burkholderia cocovenenas. Stapleton et al. [86], reported degradation of phenanthrene, naphthalene and anthracene in a soil contaminated with coal spoil at $\mathrm{pH} 2.0$ was evaluated for a period of 28 days. Removal of phenanthrene was $50 \%$ and of naphthalene and anthracene was $10 \%$ and $20 \%$ respectively. Nutrients play a vital role for successful biodegradation of PAHs. For an efficient biodegradation, growth and cellular metabolism ratio of $\mathrm{C}: \mathrm{N}$ : $\mathrm{P}$ is highly critical. However, higher concentration of nutrients can also have an adverse effect on biodegradability. Therefore some nutrients can become a limiting factor affecting the process of degradation. High demands of nutrients by plants make the fresh water wet lands nutrient deficient [87].

\section{Microbial Metabolism of PAHs}

Prokaryotes are considered as major decomposers of organic compounds in an ecosystem [88]. Microbes are able to degrade parent compound and substituted PAHs in various environments under aerobic or anaerobic conditions [89, 90]. However, there exist a significant difference in the mechanism of PAH metabolism amongst prokaryote and eukaryotic organisms. Kasnter et al. [91], reported that Gordona, Nocardia, Mycobacterium and Rhodococcus play a key role in degradation of high molecular weight PAH in soil environment. The three main pathways for polycyclic aromatic hydrocarbon degradation by fungi and bacteria are shown below in Fig. (6) [45]. Pointing [92, 93] reported 
that the member of basidiomycetous group of organisms extensively mineralized the recalcitrant PAHs because of their ability to produce ligninolytic enzymes. Anaerobic metabolism of PAHs is thought to occur via the hydrogenation of the aromatic ring [93].

\section{Bacterial Metabolism of PAHs}

Different species of bacteria have been reported for their ability to degrade the PAHs. Bacteria degrade PAH compounds by an assimilative process where they gain carbon and energy for their growth, which leads to mineralization of the compound [48, 94]. The principal mechanism of PAH degradation by bacteria involves its activation and oxidation by enzymes which catalyzes the fixation of oxygen. There are two groups of oxygenases $i . e$. mono and di oxygenases which incorporate two oxygen atoms into the aromatic ring to form cis-dihydrol. The cisdihydrol formed are then steroselectively dehydrogenated by cis-dihydrol dehydrogenase which rearomatize the benzene nucleus to form dihydroxylated intermediate (Catechol). Aromatic ring fission of these intermediate occur by the catalytic activity of stero and region selective dioxygenase. The initial ring oxidation is the rate limiting step in the biodegradation of PAH after which the degradation proceeds quickly with very less accumulation of intermediates. The common intermediates produced are catechol, gentisic acids and protocatechuic acid. Thereafter the metabolites are transformed to organic acids and aldehydes [95].

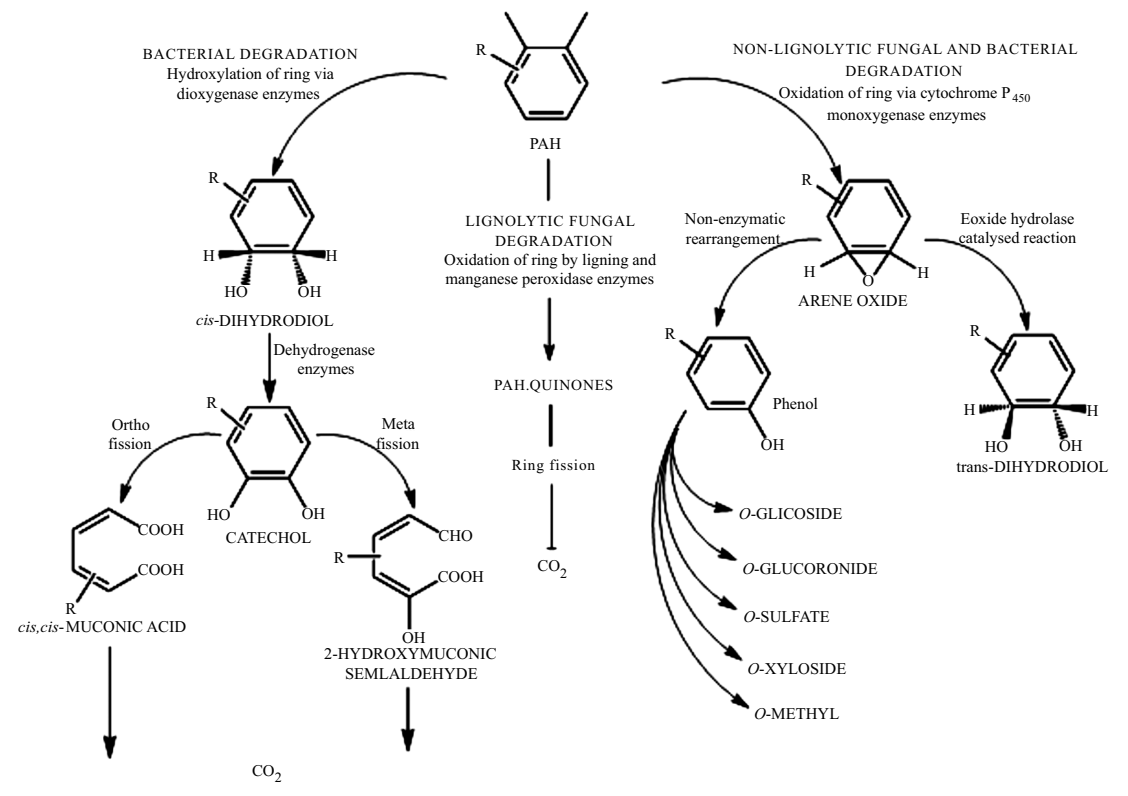

Fig. (6). Pathway showing microbial metabolism by bacteria and fungi.

Bacterial catabolism of naphthalene and phenanthrene has been studied extensively. Many bacteria capable of degrading high molecular weight PAH have been reported. Some of the bacterial species involved in degradation of PAHs are as follows: Achromobacter sp. Arthrobacter sp. Bacillus sp. Mycobacterium sp. Burkholderia sp. Pseudomonas sp. Rhodococcus sp. Stenotrophomonas maltophilia, Sphingomonas sp. Xanthamonas sp. Cerniglia [29] suggested that the initial ring oxidation is the rate limiting step in the biodegradation reaction of PAHs. As mentioned in Fig. (7) acetyl CoA and acetaldehyde are the products obtained by ortho and meta pathway respectively. The by-product of these reactions is the production of carbon- di-oxide and water [15]. Gram- negative bacteria, such as Burkholderia ( $\beta$ - proteobacteria) can easily degrade 2 or 3 ring PAHs, where as gram-positive bacteria, such as Mycobacterium, are more efficient in degrading higher ring PAHs [25]. The bacterial consortium (DV-Al) has the ability to degrade naphthalene at a growth rate of $0.0389 \mathrm{~g} \mathrm{~h}-1$ and at a rate of $80 \mathrm{mg} / \mathrm{hr}$ [96]. Wasify and Hamel [97] studied the degradation of crude oil over a period of 28 days and reported its degradation as $88.5 \%$ by consortium, $77.8 \%$ by Pseudomonas aeruginosa, $76.7 \%$ Bacillus subtilis and $74.3 \%$ by Acinetobacter lwoffi. PAHs like Fluoranthene and Phenanthrene have been used as a sole source of carbon by Spingomonas sp. [61]. Four or more fused benzene rings PAH (Phenanthrene, Pyrene and Fluoranthene) have been degraded by Mycobacterium. This may be because of the hydrophobic cell surface which helps in adhesion of insoluble PAH thereby facilitating mass transfer of the substrates to cell $[30,98]$. The process of degradation of PAH is always affected by environment factors like temperature, moisture 
and nutrient supply. The isolate Pseudoxanthomonas sp. DMVP2 degrades 300ppm of Phenanthrene within 120 hrs [99].

\section{Fungal Metabolism of PAHs}

Like bacteria, fungi also play an important role in bioremediation of PAH in nature. Although the use of PAH as the sole source of carbon by fungi has not been reported extensively. However, several studies have shown that a wide taxonomic and phylogenic spectrum of fungi have the capacity to transform PAH co-metabolically using their enzymatic machinery. A diverse group of lignolytic and non-lignolytic fungi are able to oxidize PAH. Two main groups of enzymes are involved in the initial attack on PAHs by fungi. They are Cytochrome P-450 mono oxygenase and lignin degrading enzyme system. The mechanism of PAH metabolism by non-lignolytic fungi involves the oxidation of aromatic ring by Cytochrome P-450 mono oxygenase [100, 101]. They generally incorporate one atom of oxygen into the aromatic nucleus and reduce the remaining atom to water, followed by enzymatic addition water to yield cis/transdihydrodiols [102]. Arene oxide formed can then undergo non-enzymatic rearrangement to form phenol which can further be conjugated with glucose, xylose, gluconeric acid and sulfate. Various non-lignolytic fungi like $A$. niger, $C$. elegans, P. janthinellum used Cytochrome P 450 monoxygenase for the oxidative degradation of PAH. The most widely studied non-lignolytic fungus is C. elegans. An example of Cytochrome P450 - mediated oxidation of Phenanthrene is shown in Fig. (8)[98].

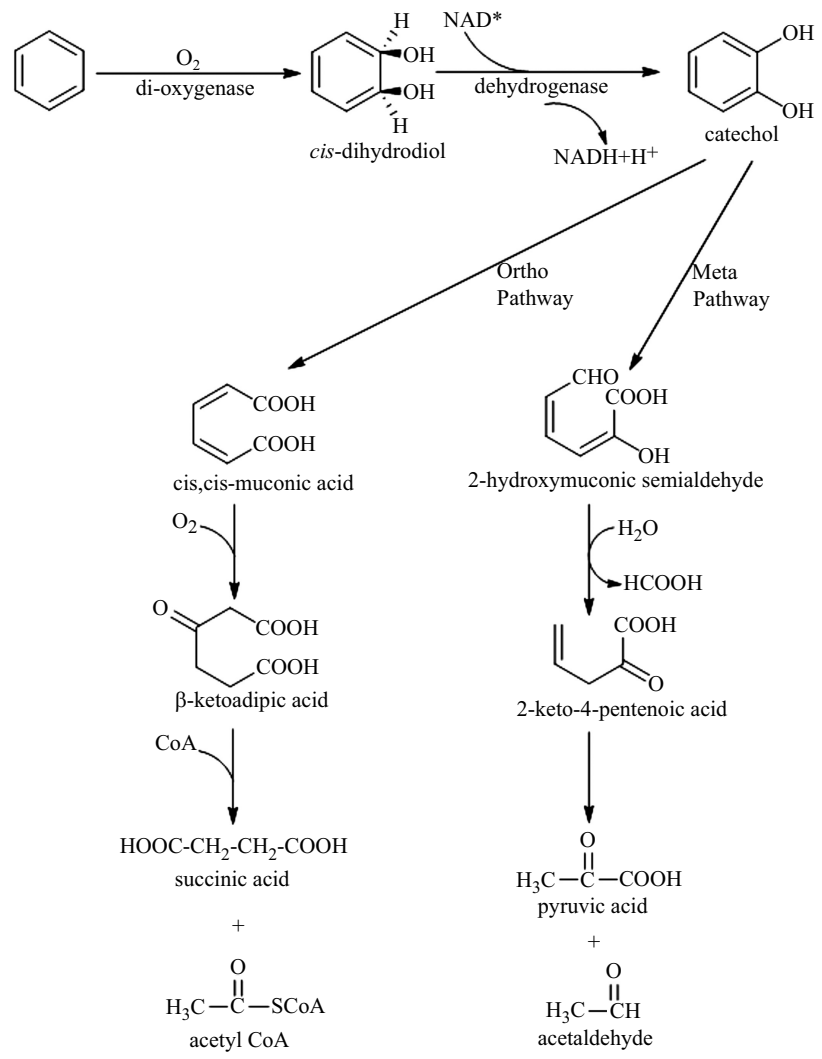

Fig. (7). Microbial Metabolism of the aromatic ring by ortho or meta cleavage (adapted from Cerniglia, 1984 [15]).

\section{Ligninolytic Fungi}

Ligninolytic fungi commonly known as white rot fungi as it causes white rot of woods. White rot fungi have been screened for PAH degrading abilities when grown under ligninolytic and non-ligninolytic culture condition. The generas of Phanerochaete, Trametes, Bjerkandera and Pleurotus have shown considerable potential for the degradation of PAH [103, 104]. The white rot fungi produce extracellular lignin degrading enzyme which have the potential to degrade xenobiotic compounds. Fungal extracellular enzymes responsible for the degradation of lignin, LiP, MnP and laccase are believed to be involoved in the degradation of PAHs [105, 106]. Ligninolytic fungi find wide spread application in biodegradation of $\mathrm{PAH}$ to $\mathrm{CO}_{2}$ and $\mathrm{O}_{2}$. Phanerochaete chrysosporium has been generally used as model organism to study potential for degradation of PAH. Initial attack of Phanerochaete chrysosporium under culture 
condition that favour lignolysis is catalysed by enzymes like LiP and MnP. Some of the white rot fungi metabolize PAH to their quinones and other metabolites that do not appear to involve a cis-trans dihydrodiol [107]. White rot fungi has the ability to produce metabolites with a higher water solubility and chemical reactivity than the parent PAH. Mono or dihydroxylated PAH metabolites could be substrates for bacteria and their degradation a reaction in soil is caused by indigenous micro flora [30]. Manganese peroxidase is thought to work through a similar mechanism of electron oxidation with diffusible oxidizing agent $\mathrm{Mn}^{+3}$ - chelate, which is a weak oxidant [108]. It is incapable of oxidizing PAHs with ionization potentials equal to or greater than chrysene $(5-7.8 \mathrm{eV})$. The system mediated by the peroxidation of unsaturated lipids by $\mathrm{MnP}$ and $\mathrm{Mn}^{+3}$ was reported to catalyze the oxidative cleavage of phenanthrene to diphenic acid [109]. Application of laccase in PAH degradation has been well studied. Laccase catalyzes one electron oxidation of PAHs such as Anthracene and Benzo (a) Pyrene both having ionization potentials 57.55eV. Collins et al. [110], reported degradation of anthracene and Benzo (a) Pyrene using Trametes versicolor by crude as well as two purified isoenzymes . Level of oxidation of athracene was higher by two purified laccase with ABTS [110]. Phenanthrene is oxidized initially to Phenanthrene- 9, 10-quinone and thereafter by the process of ring cleavage to 2.2 '-diphenic acid by Phanerochaete chrysosporium [111, 112]. as shown in Fig. (8). It was observed that maximum degradation of $84.98 \%$ was obtained on the $15^{\text {th }}$ day of incubation by Agaricomycetes sp AGAT [113]. Sack et al. [114], reported 13.8\% of degradation of pyrene after 63 days of incubation by Trametes versicolor. Lea et al. [115], reported that when Pleurotus ostreatus was grown in the presence of [14C] Pyrene, 91\% pyrene was metabolized. Hadibarata and Teh [116] reported that maximum degradation rate $(99 \%)$ was obtained at $10 \mathrm{ppm}$ concentration after incubation of 30 days.

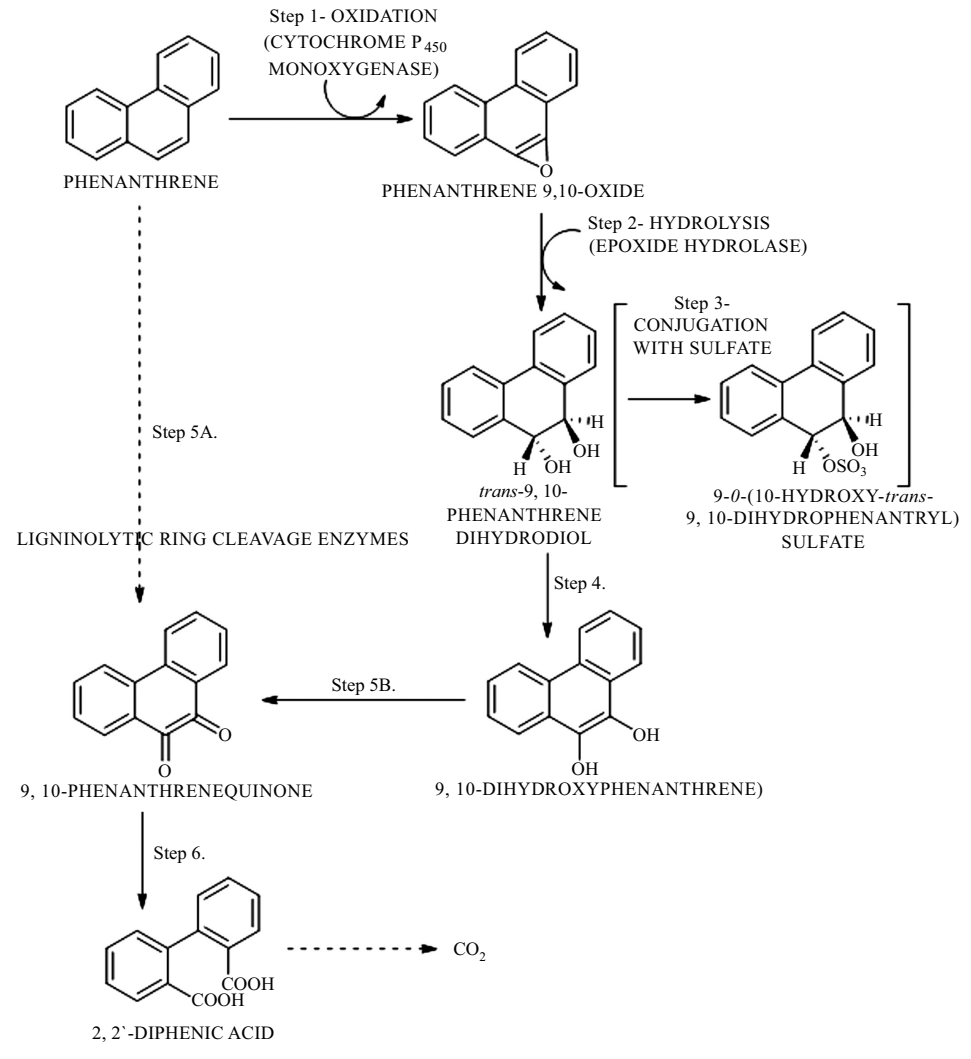

Fig. (8). Proposed pathway for the degradation of phenanthrene by the ligninolytic fungus pleurotus ostreatus (Bezalel et al., 1996 [93]).

PAH are formed during the incomplete combustion of organic material and in connection with the worldwide use of oil, gas, coal and wood in energy production. The wide spread sources of PAHs present everywhere, make them a complex mixtures of chemicals, including derivates of PAH. Exposure to PAHs or their derivatives at workplace or in house have an adverse effect on the human body. Therefore health risk evaluation is necessary.

Various government agencies worldwide have established stringent norms relating to the PAH in air, soil and water. OSHA in USA has established the permissible PAH limit to $0.2 \mathrm{mg} / \mathrm{m}^{3}$ for 8 hour TWA (Time-weighed average) [117]. NIOSH in USA has recommended the limit of $0.1 \mathrm{mg} / \mathrm{m}^{3}$ for coal tar pitch [118]. EPA has suggested that the intake of 
individual PAH which is not likely to be deleterious on human body at the level is: Anthracene (0.3 mg), Phenathrene $(0.04 \mathrm{mg})$ and Pyrene $(0.03 \mathrm{mg})$ per $\mathrm{kg}$ of body weight. Total exposure of PAH should not exceed $3 \mathrm{mg} / \mathrm{day}$ [119]. EPA has also decided the concentration of Benzo (a) pyrene not to exceed $0.2 \mathrm{ppb}$ in water as it is considered to be the most carcinogenic PAH [120].

\section{CONCLUSION}

Polycyclic aromatic hydrocarbons (PAHs) are the set of compounds known as polycyclic organic matters (POM). They are an important part of environment contaminants which are originally produced from incomplete combustion of organic materials or pyrolysis of organic materials. The fate of PAH in nature is of great environmental concern due to its mutagenic and carcinogenic toxicity. Biodegradation of PAHs and other xenobiotic compounds depend upon micro organisms to either transform or mineralize them to $\mathrm{CO}_{2}$ and $\mathrm{H}_{2} \mathrm{O}$. The present study notes that the effective depolluting of PAH from contaminated site with the help of physical, chemical, combined bioremediation and phytoremediation approaches appear to be most efficient and cost effective environmental friendly to decontaminate PAH. The development and use of genetically modified organisms represent the research friendlier environment. However, the release of such organism is always questionable. Therefore, based on the present review it may be concluded that the use of microbes is a green degradation method for the cleanup of the PAH contaminated sites.

\section{CONFLICT OF INTEREST}

The authors confirm that this article content has no conflict of interest.

\section{ACKNOWLEDGEMENTS}

The authors are grateful to Department of Biotechnology (BT/PR7567/BCE/8/1005/2013), Ministry Of Science and Technology Govt. of India, New Delhi for their financial support and Sophisticated Instrumentation Centre for Applied Research and Testing (SICART) for providing instrumentation facility for the successful completion of this work.

\section{REFERENCES}

[1] Vila J, Grifoll M. Actions of Mycobacterium sp. strain AP1 on the saturated and aromatic-hydrocarbon fractions of fuel oil in a marine medium. Appl Environ Microbiol 2009; 75(19): 6232-9.

[http://dx.doi.org/10.1128/AEM.02726-08] [PMID: 19666730]

[2] Luke NU, Ubaezue UE, Pascal CN, Christopher IA. Nwoko, Jude IA. Polycyclic aromatic hydrocarbons degradation techniques: a review. Int J Chem 2013; 5: 43-55.

[3] Fetzer JC. The chemistry and analysis of the large Polycyclic Aromatic Hydrocarbon. New York: Wiley 2000; pp. 27-9.

[4] Holliger C, Gaspard S, Glod G, et al. Contaminated environments in the subsurface and bioremediation: organic contaminants. FEMS Microbiol Rev 1997; 20(3-4): 517-23. [http://dx.doi.org/10.1111/j.1574-6976.1997.tb00334.x] [PMID: 9299718]

[5] Mrozik A, Piotrowska Z, Labuzek S. Bacterial degradation and bioremediation of polycyclic aromatic hydrocarbons. Pol J Environ Stud 2003; 12: $15-25$.

[6] Balaji V, Arulazhagan P, Ebenezer P. Enzymatic bioremediation of polycyclic hydrocarbons by fungal consortia enriched from petroleum contaminated soil and oil seeds. J Environ Biol 2013; 35: 1-9.

[7] Arulazhagan P, Vasudevan N. Role of nutrients in the utilization of polycyclic aromatic hydrocarbons by halotolerant bacterial strain. J Environ Sci (China) 2011; 23(2): 282-7. [http://dx.doi.org/10.1016/S1001-0742(10)60404-4] [PMID: 21517002]

[8] Hamamura N, Ward DM, Inskeep WP. Effects of petroleum mixture types on soil bacterial population dynamics associated with the biodegradation of hydrocarbons in soil environments. FEMS Microbiol Ecol 2013; 85(1): 168-78. [http://dx.doi.org/10.1111/1574-6941.12108] [PMID: 23488682]

[9] Hadibarata T, Tachibana S, Itoh K. Biodegradation of chrysene, an aromatic hydrocarbon by Polyporus sp. S133 in liquid medium. J Hazard Mater 2009; 164(2-3): 911-7.

[http://dx.doi.org/10.1016/j.jhazmat.2008.08.081] [PMID: 18835091]

[10] Cerniglia CE, Sutherland JB. Degradation of polycyclic aromatic hydrocarbons by fungi. In: Handbook of hydrocarbon and lipid microbiology. 2010; pp. 2079-110. [http://dx.doi.org/10.1007/978-3-540-77587-4_151]

[11] Muñoz R, Guieysse B, Mattiasson B. Phenanthrene biodegradation by an algal-bacterial consortium in two-phase partitioning bioreactors. Appl Microbiol Biotechnol 2003; 61(3): 261-7.

[http://dx.doi.org/10.1007/s00253-003-1231-9] [PMID: 12698286] 
[12] Chan SM, Luan T, Wong MH, Tam NF. Removal and biodegradation of polycyclic aromatic hydrocarbons by Selenastrum capricornutum. Environ Toxicol Chem 2006; 25(7): 1772-9. [http://dx.doi.org/10.1897/05-354R.1] [PMID: 16833137]

[13] Miller EC, Miller JA. Searches for ultimate chemical carcinogens and their reactions with cellular macromolecules. Cancer 1981; 47(10): $2327-45$. [http://dx.doi.org/10.1002/1097-0142(19810515)47:10<2327::AID-CNCR2820471003>3.0.CO;2-Z] [PMID: 7272889]

[14] Samanta SK, Singh OV, Jain RK. Polycyclic aromatic hydrocarbons: environmental pollution and bioremediation. Trends Biotechnol 2002; 20(6): 243-8.

[http://dx.doi.org/10.1016/S0167-7799(02)01943-1] [PMID: 12007492]

[15] Cerniglia CE. Microbial metabolism of polycyclic aromatic hydrocarbons. Adv Appl Microbiol 1984; 30: 31-71. [http://dx.doi.org/10.1016/S0065-2164(08)70052-2] [PMID: 6442534]

[16] Wang DG, Yang M, Jia HL, Zhou L, Li YF. Polycyclic aromatic hydrocarbons in urban street dust and surface soil: comparisons of concentration, profile, and source. Arch Environ Contam Toxicol 2009; 56(2): 173-80. [http://dx.doi.org/10.1007/s00244-008-9182-x] [PMID: 18560924]

[17] Wilson SC, Jones KC. Bioremediation of soil contaminated with polynuclear aromatic hydrocarbons (PAHs): a review. Environ Pollut 1993; 81(3): 229-49. [http://dx.doi.org/10.1016/0269-7491(93)90206-4] [PMID: 15091809]

[18] Kastner M. Degradation of aromatic and polyaromatic compounds. In: Rehm H-J, Reed G, Eds. Biotechnology, Vol 11b. Weinheim, Germany: Wiley-VCH 2008; pp. 211-39.

[19] Harvey RG. Polycyclic aromatic hydrocarbons. N.Y: Wiley-VCH New York 1997.

[20] Hesham AL, Mawad AM, Mostafa YM, Shoreit A. Biodegradation Ability and Catabolic Genes of Petroleum-Degrading Sphingomonas koreensis Strain ASU-06 Isolated from Egyptian Oily Soil. BioMed Res Int 2014; 01-10. Article ID 127674.

[21] Hussein IA, Mona SM. A review on PAHs: Source, Environmental impact, effect on human health and remediation Egyptian. J Petrol 2016; 25: 107-23.

[22] Arey J, Atkinson R. Photochemical reactions of polycylic aromatic hydrocarbon in the atmosphere. In: Douben PE, Ed. PAHs: an ectotoxicological perspective. New York: John Wiley and Sons Ltd 2003; pp. 47-63. [http://dx.doi.org/10.1002/0470867132.ch4]

[23] Toro DM, McGrath JA, Hansen DJ. Technical basis for narcotic chemicals and polycyclic aromatic hydrocarbon criteria. I. Water and tissue. Environ Toxicol Chem 2000; 19: 1951-70.

[http://dx.doi.org/10.1002/etc.5620190803]

[24] Blumer M. Polycyclic aromatic compounds in nature. Sci Am 1976; 234(3): 35-45. [http://dx.doi.org/10.1038/scientificamerican0376-34] [PMID: 1251182]

[25] Johnsen AR, Wick LY, Harms H. Principles of microbial PAH-degradation in soil. Environ Pollut 2005; 133(1): 71-84. [http://dx.doi.org/10.1016/j.envpol.2004.04.015] [PMID: 15327858]

[26] Haritash AK, Kaushik CP. Biodegradation aspects of polycyclic aromatic hydrocarbons (PAHs): a review. J Hazard Mater 2009; 169(1-3): $1-15$. [http://dx.doi.org/10.1016/j.jhazmat.2009.03.137] [PMID: 19442441]

[27] Okere UV, Semple KT. Biodegradation of PAHs in 'pristine' soils from different climatic regions. J Bioremed Biodegrad 2012; pp. 1-11.

[28] Ashok BT, Saxena S, Musarrat J. Isolation and characterization of four polycyclic aromatic hydrocarbon degrading bacteria from soil near an oil refinery. Lett Appl Microbiol 1995; 21(4): 246-8. [http://dx.doi.org/10.1111/j.1472-765X.1995.tb01052.x] [PMID: 7576515]

[29] Cerniglia CE. Biodegradation of polycyclic aromatic hydrocarbons. Biodegradation 1992; 3(2): 351-68.

[30] Cerniglia CE. Biodegradation of polycyclic aromatic hydrocarbons. Curr Opin Biotechnol 1993; 4: 331-8. [http://dx.doi.org/10.1016/0958-1669(93)90104-5]

[31] Lundstedt S, Haglund P, Oberg L. Degradation and formation of polycyclic aromatic compounds during bioslurry treatment of an aged gasworks soil. Environ Toxicol Chem 2003; 22(7): 1413-20. [http://dx.doi.org/10.1002/etc.5620220701] [PMID: 12836964]

[32] Bojes HK, Pope PG. Characterization of EPAs 16 priority pollutant polycyclic aromatic hydrocarbons (PAHs) in tank bottom solids and associated contaminated soils at oil exploration and production sites in Texas. Regul Toxicol Pharmacol 2007; 47(3): 288-95. [http://dx.doi.org/10.1016/j.yrtph.2006.11.007] [PMID: 17291653]

[33] Harvey RG. Environmental Chemistry of PAHs.. Chapter: PAHs and Related Compounds. In: The handbook of Environmental Chemistry . 1998; pp. 01-54.

[http://dx.doi.org/10.1007/978-3-540-49697-7_1]

[34] Ramesh A, Walker SA, Hood DB, Guillén MD, Schneider K, Weyand EH. Bioavailability and risk assessment of orally ingested polycyclic aromatic hydrocarbons. Int J Toxicol 2004; 23(5): 301-33. [http://dx.doi.org/10.1080/10915810490517063] [PMID: 15513831] 
[35] Sikkema J, de Bont JA, Poolman B. Mechanisms of membrane toxicity of hydrocarbons. Microbiol Rev 1995; 59(2): 201-22. [PMID: 7603409]

[36] Pierzynski GM, Hettiarachchi GM, Ransom MD. Insitu stabilization of soil lead using phosphorus and manganese oxide. Environ Sci Technol 2000; 34(21): 4614-9. [http://dx.doi.org/10.1021/es001228p]

[37] Dabestani RI, Ivanov A. Compilation of physical, spectroscopic and photophysical properties of polycyclic aromatic hydrocarbons. Photochem Photobiol 1999; 70(1): 10-34.

[38] Park KS, Sims RC, Dupont R. Transformations of PAHs in soil systems. J Environ Eng 1990; 116: 632-40. [http://dx.doi.org/10.1061/(ASCE)0733-9372(1990)116:3(632)]

[39] Yuan SY, Wei SH, Chang BV. Biodegradation of polycyclic aromatic hydrocarbons by a mixed culture. Chemosphere 2000; 41(9): 1463-8. [http://dx.doi.org/10.1016/S0045-6535(99)00522-6] [PMID: 11057584]

[40] Kom RR, Mbawala A, Ngassoum MB. Naphthalene biodegradation by microbial consortia isolated from soils in Ngaoundere (Cameroon). Int J Envirn Sci 2012; 3(1): 1-10.

[41] Semple KT, Morriss AW, Paton GI. Bioavailability of hydrophobic organic contaminants in soils: fundamental concepts and techniques for analysis. Eur J Soil Sci 2003; 54: 809-18. [http://dx.doi.org/10.1046/j.1351-0754.2003.0564.x]

[42] Reid BJ, Jones KC, Semple KT. Bioavailability of persistent organic pollutants in soils and sedimentsa perspective on mechanisms, consequences and assessment. Environ Pollut 2000; 108(1): 103-12. [http://dx.doi.org/10.1016/S0269-7491(99)00206-7] [PMID: 15092971]

[43] Muñoz R, Guieysse B, Mattiasson B. Phenanthrene biodegradation by an algal-bacterial consortium in two-phase partitioning bioreactors. Appl Microbiol Biotechnol 2003; 61(3): 261-7. [http://dx.doi.org/10.1007/s00253-003-1231-9] [PMID: 12698286]

[44] Rockne KJ, Strand SE. Biodegradation of bicyclic and polycyclic aromatic hydrocarbons in aerobic enrichments. Environ Sci Technol 1998; 32: $2962-7$.

[http://dx.doi.org/10.1021/es980368k]

[45] Bamforth SM, Singleton I. Bioremediation of polycyclic aromatic hydrocarbons. J Chem Technol Biotechnol $2005 ; 80: 723-36$. [http://dx.doi.org/10.1002/jctb.1276]

[46] Aishatu UM, Maryam UM. Microbial metabolism of polycyclic aromatic hydrocarbons (PAHs): a review. Int J Eng Sci 2015 ; 6: 1449-58.

[47] Harms H. Bioavailability and bioaccessibility as key factors in bioremediation. In: Moo-Young M, Agathos S, Eds. Comprehensive Biotechnology. $2^{\text {nd }}$ ed. Spain: Elsevier 2011; pp. 83-94. [http://dx.doi.org/10.1016/B978-0-08-088504-9.00367-6]

[48] Winquist E, Bjorklof K, Schultz E, et al. Bioremediation of PAH-contaminated soil with fungi- From laboratory to field scale. Int Biodeter Biodegr 2014; 86: 238-47

[http://dx.doi.org/10.1016/j.ibiod.2013.09.012]

[49] Maeir RM, Pepper KT, Gerba PC. A textbook of Environmental Microbiology. CA: Academic Press San Diego 2000.

[50] Semple KT, Doick KJ, Jones KC, Burauel P, Craven A, Harms H. Defining bioavailability and bioaccessibility of contaminated soil and sediment is complicated. Environ Sci Technol 2004; 38(12): 228A-31A. [http://dx.doi.org/10.1021/es040548w] [PMID: 15260315]

[51] Aronstein BN, Alexander M. Surfactants at low concentrations stimulate biodegradation of sorbed hydrocarbons in samples of aquifer sands and soil slurries. Environ Toxicol Chem 1992; 11(9): 1227-33. [http://dx.doi.org/10.1002/etc.5620110903]

[52] Harmsen J. Measuring bioavailability: from a scientific approach to standard methods. J Environ Qual 2007; 36(5): 1420-8. [http://dx.doi.org/10.2134/jeq2006.0492] [PMID: 17766821]

[53] Alexander M. How toxic are toxic chemicals in soil? Environ Sci Technol 1995; 29(11): 2713-7. [http://dx.doi.org/10.1021/es00011a003] [PMID: 22206515]

[54] Uyttebroek M, Breugelmans P, Janssen M, et al. Distribution of the mycobacterium community and polycyclic aromatic hydrocarbon (PAHs) among different size fractions of a long-term PAH-contaminated soil. Environ Microbiol 2007; 8: 838-47.

[55] Renner R. EPA to strengthen persistent, bioaccumulative, and toxic pollutant controls-Mercury first to be targeted. Environ Sci Technol 1999; 33(3): 62A. [http://dx.doi.org/10.1021/es992653p] [PMID: 21662455]

[56] Gibson DT, Subramanian V. In Microbial degradation of Organic Compounds. Marcel Dekker: New York 1984; pp. 181-252.

[57] VanRooij JG, Bodelier-Bade MM, Jongeneelen FJ. Estimation of individual dermal and respiratory uptake of polycyclic aromatic hydrocarbons in 12 coke oven workers. Br J Ind Med 1993; 50(7): 623-32. [PMID: 8343423]

[58] Sims RC, Overcash R. Fate of polynuclear aromatic compounds (PNAs) in soil-plant systems. Residue Rev 1983; 88: 1-68. 
[59] Mersch-Sundermann V. Mochayedi, Kevekordes S.Genotoxicity of polycyclic aromatic hydrocarbons in Escherichia coli PQ37. Mutat Resgenet Tox 1992; 278(1): 1-9. [http://dx.doi.org/10.1016/0165-1218(92)90279-9]

[60] Nylund A, Houland K, Hodneland F, Nilsen F, Lovik P. Mechanisms for transmission of infectious Salmon anemia (ISA). Dis Aquat Organ 1994; 19: 95-100 [http://dx.doi.org/10.3354/dao019095]

[61] Kanaly RA, Harayama S. Biodegradation of high-molecular-weight polycyclic aromatic hydrocarbons by bacteria. J Bacteriol 2000; 182(8): 2059-67.

[http://dx.doi.org/10.1128/JB.182.8.2059-2067.2000] [PMID: 10735846]

[62] Eriksson M, Sodersten E, Yu Z, Dalhammar G, Mohn WW. Degradation of polycyclic aromatic hydrocarbons at low temperature under aerobic and nitrate-reducing conditions in enrichment cultures from northern soils. Appl Environ Microbiol 2003; 69(1): 275-84. [http://dx.doi.org/10.1128/AEM.69.1.275-284.2003] [PMID: 12514005]

[63] Tao L, Mogilner A, Civelekoglu-Scholey G, et al. A homotetrameric kinesin-5, KLP61F, bundles microtubules and antagonizes Ncd in motility assays. Curr Biol 2006; 16(23): 2293-302. [http://dx.doi.org/10.1016/j.cub.2006.09.064] [PMID: 17141610]

[64] Selina MB, Ian S. Review: Bioremediation of polycyclic aromatic hydrocarbons: current knowledge and future directions. J Chem Technol Biotechnol 2005; 80: 723-36. [http://dx.doi.org/10.1002/jctb.1276]

[65] Harvey RG. Mechanisms of carcinogens of polycyclic aromatic hydrocarbons. Polycycl Aromat Compd 1996; 9: 1-23. [http://dx.doi.org/10.1080/10406639608031196]

[66] Chang BV, Shiung LC, Yuan SY. Anaerobic biodegradation of polycyclic aromatic hydrocarbon in soil. Chemosphere 2002; 48(7): 717-24. [http://dx.doi.org/10.1016/S0045-6535(02)00151-0] [PMID: 12201202]

[67] Prak DJ, Pritchard PH. Solubilization of polycyclic aromatic hydrocarbon mixtures in micellar nonionic surfactant solutions. Water Res 2002; 36(14): 3463-72.

[http://dx.doi.org/10.1016/S0043-1354(02)00070-2] [PMID: 12230191]

[68] Boonchan S. britz ML, Stanley GA. Surfactant enhanced biodegradation of high molecular weight polycyclic aromatic hydrocarbon by Stenotrophomonas maltophilia. Biotechnol Bioeng 1998; 59: 482-94. [http://dx.doi.org/10.1002/(SICI)1097-0290(19980820)59:4<482::AID-BIT11>3.0.CO;2-C] [PMID: 10099362]

[69] Li JL, Chen BH. Effect of nonionic surfactants on biodegradation of phenanthrene by a marine bacteria of Neptunomonas naphthovorans. J Hazard Mater 2009; 162(1): 66-73.

[http://dx.doi.org/10.1016/j.jhazmat.2008.05.019] [PMID: 18554784]

[70] Mueller JG, Devereux R, Santavy DL, Lantz SE, Willis SG, Pritchard PH. Phylogenetic and physiological comparisons of PAH-degrading bacteria from geographically diverse soils. Antonie van Leeuwenhoek 1997; 71(4): 329-43. [http://dx.doi.org/10.1023/A:1000277008064] [PMID: 9195008]

[71] Alexander M. Biodegradation and Bioremediation. $2^{\text {nd }}$ ed. San Diego, USA: Academic Press Inc 1994; pp. $248-50$.

[72] Nilanjana D, Preethy C. Microbial degradation of petroleum hydrocarbon contaminants: An overview. Biotechnol Res Int 2011. Article ID 941810:13.

[73] Gratia E, Weekers F, Margesin R, DAmico S, Thonart P, Feller G. Selection of a cold-adapted bacterium for bioremediation of wastewater at low temperatures. Extremophiles 2009; 13(5): 763-8. [http://dx.doi.org/10.1007/s00792-009-0264-0] [PMID: 19578929]

[74] Epuri V, Sorensen D. Benzo (a) pyrene and hexachlorobiphenyl contaminated soil: phytoremediation potential. $6^{\text {th }}$. Washing DC: American Chemical Society Press. 1997.

[75] Newman LA, Reynolds CM. Phytodegradation of organic compounds. Curr Opin Biotechnol 2004; 15(3): 225-30. [http://dx.doi.org/10.1016/j.copbio.2004.04.006] [PMID: 15193330]

[76] Adam G, Ducan H. Effect of diesel fuel on growth of selected plant species. Environ Geochem Health 1999; 21: 353-7. [http://dx.doi.org/10.1023/A:1006744603461]

[77] Chen YC. Banks Mk, Schwab AP. Pyrene degradation in the rhizosphere of tall fescue (Festuca arundinacea) and switch grass (Panicum virgatum). Environ Sci Technol 2003; 37: 5778-82. [http://dx.doi.org/10.1021/es030400x] [PMID: 14717195]

[78] Hong PK, Nakra S, Jimmy Kao CM, Hayes DF. Pressure-assisted ozonation of PCB and PAH contaminated sediments. Chemosphere 2008; 72(11): 1757-64. [http://dx.doi.org/10.1016/j.chemosphere.2008.04.061] [PMID: 18547611]

[79] Haapea P, Tuhkanen T. Integrated treatment of PAH contaminated soil by soil washing, ozonation and biological treatment. J Hazard Mater 2006; 136(2): 244-50 [http://dx.doi.org/10.1016/j.jhazmat.2005.12.033] [PMID: 16455197]

[80] Ukiwe LN, Egereonu UU, Njoku PC, Nwoko CI. Combined chemical and water hyacinth (Eichhornia crassipes) treatment of PAHs 
contaminated soil. Int J Sci Eng Res 2013; 4: 1-12.

[81] Bartha R, Bossert I. The treatment and disposal of petroleum wastes in Petroleum Microbiology. New York, NY, USA: Macmillan 1984; pp. 553-78.

[82] Cooney JJ. The fate of petroleum pollutants in fresh water ecosystems In: Atlas RM, Ed. Petroleum Microbiology. New York, NY, USA: Macmillan 1984; pp. 399-434.

[83] Siron R, Pelletier E, Brochu H. Environmental factors influencing the biodegradation of petroleum hydrocarbons in cold sea water. Arch Environ Contam Toxicol 1995; 28: 406-16. [http://dx.doi.org/10.1007/BF00211621]

[84] Lau KL, Tsang YY, Chiu SW. Use of spent mushroom compost to bioremediate PAH-contaminated samples. Chemosphere 2003; 52(9): $1539-46$.

[http://dx.doi.org/10.1016/S0045-6535(03)00493-4] [PMID: 12867186]

[85] Wong JW, Lai KM, Wan CK, Ma KK, Fang M. isolation and optimisation of PAH-degradative bacteria from contaminated soil for PAH bioremediation. Water Air Soil Pollut 2002; 139: 1-13.

[http://dx.doi.org/10.1023/A:1015883924901]

[86] Stapleton RD, Savage DC, Sayler GS, Stacey G. Biodegradation of aromatic hydrocarbons in an extremely acidic environment. Appl Environ Microbiol 1998; 64(11): 4180-4.

[PMID: 9797263]

[87] Mitsch WJ, Gosselink JG. Wetlands. $2^{\text {nd }}$ ed. New York, NY, USA: John Wiley \& Sons 1993.

[88] Campbell NA, Reece JB. Biology Pearson. Benjamin Cummings 2005; pp. 436-90.

[89] Baek KH, Kim HS, Oh HM, Yoon BD, Kim J, Lee IS. Effects of crude oil, oil components, and bioremediation on plant growth. J Environ Sci Health A Tox Hazard Subst Environ Eng 2004; 39(9): 2465-72. [http://dx.doi.org/10.1081/ESE-200026309] [PMID: 15478936]

[90] Yang K, Deutsch J, Gelboin V. Polycyclic hydrocarbons and cancer Environment, Chemistry and Metabolism. New York: Academic Press 1978; Vol. 1.

[91] Kastner M. Breuer-JammaliM, Mahro B. Enumeration and characterization of the soil microflora hydrocarbon-contaminated soil sites able to mineralize polycyclic aromatic hydrocarbons (PAH). Appl Microbiol Biotechnol 1994; 41: 267. [http://dx.doi.org/10.1007/BF00186971]

[92] Pointing SB. Feasibility of bioremediation by white-rot fungi. Appl Microbiol Biotechnol 2001; 57(1-2): 20-33. [http://dx.doi.org/10.1007/s002530100745] [PMID: 11693920]

[93] Aust SDPR, Swaner JD. Detoxification and metabolism of chemicals by white rot fungi. Pesticide decontamination and detoxification. . JJPCZhus SDAust AT Lemley Gan. Washington, D.C: Oxford University press 2003; pp. 3-14.

[94] Haderlein A, Legros R, Ramsay BA. Pyrene mineralization capacity increases with compost maturity. Biodegradation 2006; 17(4): 293-302. [http://dx.doi.org/10.1007/s10532-005-4217-8] [PMID: 16284924]

[95] Cébron A, Norini MP, Beguiristain T, Leyval C. Real-Time PCR quantification of PAH-ring hydroxylating dioxygenase (PAH-RHDalpha) genes from Gram positive and Gram negative bacteria in soil and sediment samples. J Microbiol Methods 2008; 73(2): 148-59. [http://dx.doi.org/10.1016/j.mimet.2008.01.009] [PMID: 18329116]

[96] Patel V, Jain S, Madamwar D. Naphthalene degradation by bacterial consortium (DV-AL) developed from Alang-Sosiya ship breaking yard, Gujarat, India. Bioresour Technol 2012; 107: 122-30.

[http://dx.doi.org/10.1016/j.biortech.2011.12.056] [PMID: 22217733]

[97] Raed SAI W, Shimaa RH. Bacterical biodegradation of crude oil using local isolate. Int J Bacteriol 2014; 2014 : 1-09. [http://dx.doi.org/http://dx.doi.org/10.1155/2014/863272]

[98] Bezalel L, Hadar Y, Fu PP, Freeman JP, Cerniglia CE. Metabolism of phenanthrene by the white rot fungus Pleurotus ostreatus. Appl Environ Microbiol 1996; 62(7): 2547-53.

[PMID: 8779594]

[99] Patel V, Cheturvedula S, Madamwar D. Phenanthrene degradation by Pseudoxanthomonas sp. DMVP2 isolated from hydrocarbon contaminated sediment of Amlakhadi canal, Gujarat, India. J Hazard Mater 2012; 201-202: 43-51. [http://dx.doi.org/10.1016/j.jhazmat.2011.11.002] [PMID: 22169141]

[100] Chang BV, Chang W, Yuan SY. Anaerobic degradation of polycyclic aromatic hydrocarbons in sludge. Adv Environ Res 2003; 7: 623-8. [http://dx.doi.org/10.1016/S1093-0191(02)00047-3]

[101] Sutherland JB, Rafii F, khan AA, Cerniglia CE. Mechanisms of polycyclic aromatic hydrocarbon degradation. In: Young LY, Cerniglia CE, Eds. Microbial Transformation and degradation of toxic organic chemicals. New York: Wiley-Liss 1995.

[102] Jerina DM. The 1982 Bernard B. brodie Award Lecture. Metabolism of Aromatic hydrocarbons by the cytochrome P-450 system and epoxide hydrolase. Drug Metab Dispos 1983; 11(1): 1-4. [PMID: 6132787]

[103] Hestbjerg H, Willumsen PA, Christensen M, Andersen O, Jacobsen CS. Bioaugmentation of tar-contaminated soils under field conditions using Pleurotus ostreatus refuse from commercial mushroom production. Environ Toxicol Chem 2003; 22(4): 692-8. 
[http://dx.doi.org/10.1002/etc.5620220402] [PMID: 12685699]

[104] Bioremediation capabilities of white rot fungi. Review Article Spring 2004; BI570: 1-12.

[105] Mester T, Tien M. Oxidation mechanism of ligninolytic enzymes involved in the degradation of environmental pollutants. Int Biodeterior Biodegradation 2000; 46: 51-9.

[http://dx.doi.org/10.1016/S0964-8305(00)00071-8]

[106] Kirk TK, Farrell RL. Enzymatic combustion: the microbial degradation of lignin. Annu Rev Microbiol 1987; 41: 465-505. [http://dx.doi.org/10.1146/annurev.mi.41.100187.002341] [PMID: 3318677]

[107] Sutherland JB. Detoxification of polycyclic aromatic hydrocarbons by fungi. J Ind Microbiol 1992; 9(1): 53-61. [http://dx.doi.org/10.1007/BF01576368] [PMID: 1367975]

[108] Bohmer S. Messner k, Srebotnik E. Oxidation of phenanthrenr by a fungal laccase in the presence of 1-hydroxybenzotriazole and unsaturated lipids. Biochem Biophys Res Commun 1998; 244: 233-8. [http://dx.doi.org/10.1006/bbrc.1998.8228] [PMID: 9514895]

[109] Moen MA, Hammel KE. Lipid peroxidation by the manganese peroxidase of Phanerochaete chrysosporium is the basis for Phenanthrene oxidation by intact fungus. Appl Environ Microbiol 1994; 60(6): 1956-61. [PMID: 16349285]

[110] Collins PJ, Kotterman M, Field JA, Dobson A. Oxidation of Anthracene and Benzo[a]pyrene by Laccases from Trametes versicolor. Appl Environ Microbiol 1996; 62(12): 4563-7. [PMID: 16535468]

[111] Hammel KE, Gai WZ, Green B, Moen MA. Oxidative degradation of phenanthrene by the ligninolytic fungus Phanerochaete chrysosporium. Appl Environ Microbiol 1992; 58(6): 1832-8. [PMID: 1622259]

[112] Tony H, Tachibana S, Askari M. Identification of metabolites from phenathrene oxidation by phenoloxidases and dioxygenases of Polyporus sp S133. J Microbiol Biotechnol 2011; 21(3): 299-304.

[113] Tripathi A, Gupte A. Optimization for laccase production in solid state fermentation using fungal isolate agaricomycetes sp AGAT and its role in degradation of pyrene. Curr Res Microb Biotechnol 2015; 03: 781-93.

[114] Sack U, Heinze TM, Deck J, et al. Comparison of phenanthrene and pyrene degradation by different wood-decaying fungi. Appl Environ Microbiol 1997; 63(10): 3919-25. [PMID: 9327556]

[115] Lea B, Yitzhak H, Peter PF, et al. Initial oxidation products in the metabolism of pyrene, anthracene, fluorene and dibenzothiophene by the white rot fungus pleurotusostreatus. Appl Environ Microb 1996; pp. 2554-9.

[116] Hadibarata T, Teh ZC. Optimization of pyrene degradation by white-rot fungus Pleurotus pulmonarius F043 and characterization of its metabolites. Bioprocess Biosyst Eng 2014; 37(8): 1679-84. [http://dx.doi.org/10.1007/s00449-014-1140-6] [PMID: 24554082]

[117] Occupational Safety \& Health Administration (OSHA) Coal Tar Pitch Volatiles 2010. Available from: https:/www.osha.gov/ SLTC/coaltarpitchvolatiles/

[118] NIOSH (National Institute for Occupational Safety and Health) 2010. Available from: http://www.cdc.gov/niosh/about/

[119] U.S.EPA. Deposition of Air Pollutants to the Great Waters: Third Report to Congress. Office of Air Quality Planning and Standards. EPA-453/R-00-0005

[120] Agency for toxic substances disease registry (ATSDR) Toxicological profile for PAHs. Atlanta, GA: US Department of Health and Human Services, Public Health Service 1995.

(C) Gupte et al.; Licensee Bentham Open

This is an open access article licensed under the terms of the Creative Commons Attribution-Non-Commercial 4.0 International Public License (CC BY-NC 4.0) (https://creativecommons.org/licenses/by-nc/4.0/legalcode), which permits unrestricted, non-commercial use, distribution and reproduction in any medium, provided the work is properly cited. 